\title{
Article/Artigo
}

\section{Study of infection by Rickettsiae of the spotted fever group in humans and ticks in an urban park located in the City of Londrina, State of Paraná, Brazil}

\author{
Estudo da infecção por Rickettsias do grupo da febre maculosa em humanos e carrapatos de \\ um parque urbano na Cidade de Londrina, Estado do Paraná
}

\section{Roberta Santos Toledo', Katia Tamekuni ${ }^{1}$, Mauro de Freitas Silva Filho', Valeska Bender Haydu ${ }^{2}$, Richard Campos Pacheco ${ }^{3}$, Marcelo Bahia Labruna ${ }^{3}$, John Stephen Dumler ${ }^{4}$ and Odilon Vidotto}

\begin{abstract}
Introduction: Spotted fevers are emerging zoonoses caused by Rickettsia species in the spotted fever group (SFG). Rickettsia rickettsii is the main etiologic agent of Brazilian spotted fever (BSF) and it is transmitted by Amblyomma spp. ticks. Methods: The study aimed to investigate SFG rickettsiae in the Arthur Thomas Municipal Park in Londrina, PR, by collecting free-living ticks and ticks from capybaras and blood samples from personnel working in these areas. Samples from A. dubitatum and A. cajennense were submitted for PCR in pools to analyze the Rickettsia spp. gltA (citrate synthase gene). Results: All the pools analyzed were negative. Human sera were tested by indirect immunofluorescence assay with $R$. rickettsii and $R$. parkeri as antigens. Among the 34 sera analyzed, seven $(20.6 \%)$ were reactive for $R$. rickettsii: four of these had endpoint titers equal to 64,2 titers were 128 and 1 titer was 256 . None of the samples were reactive for $R$. parkeri. An epidemiological questionnaire was applied to the park staff, but no statistically significant associations were identified. Conclusions: The serological studies suggest the presence of Rickettsiae related to SFG that could be infecting the human population studied; however, analysis of the ticks collected was unable to determine which species may be involved in transmission to humans.
\end{abstract}

Keywords: Amblyomma dubitatum. Amblyomma cajennense. Rickettsia. Epidemiology. PCR.

\section{RESUMO}

Introdução: A febre maculosa é uma zoonose emergente causada por espécies de Rickettsia do grupo febre maculosa (GFM). Rickettsia rickettsii é o principal agente etiológico da febre maculosa brasileira (FMB) e é transmitida por Amblyomma spp. Métodos: Com o objetivo de obter informações sobre GFM Rickettsiae no Parque Municipal Arthur Thomas em Londrina, $\mathrm{PR}$, carrapatos de vida livre e de capivaras foram coletados, assim como amostras de sangue das pessoas que trabalham no parque. A. dubitatum e A. cajennense foram submetidos à PCR em pools para analises de Rickettsia spp. gltA (citrate synthase gene). Resultados: Todos os pools de carrapatos analizados foram negativos. Soros de humanos foram testados pela imunofluorescência indireta com antigenos de $R$. rickettsii $\mathrm{R}$. parkeri. Entre os 34 soros analisados, $7(20,6 \%)$ foram positivos para $R$. rickettsii. Destes, quatro apresentaram títulos iguais a 64, dois iguais a 128 e um, igual a 256, mas nenhum soro reagiu com $R$. parkeri. Não houve nenhuma associação, estatisticamente significante, entre as variáveis analisadas no questionário epidemiológico fornecido às pessoas que participaram da pesquisa. Conclusões: Os estudos sorológicos sugerem a presença de alguma Rickettsiae relacionada ao GFM que poderiam estar infectando a população humana estudada. Entretanto, as análises dos carrapatos foram inconclusivas para determinar qual espécie poderia estar envolvida na transmissão para os humanos. Palavras-chaves: Amblyomma dubitatum. Amblyomma cajennense. Rickettsia. Epidemiologia. PCR.

1. Programa de Pós Graduação em Ciência Animal, Universidade Estadual de Londrina, Londrina, PR 2. Residência em Medicina Veterinária Preventiva, Hospital Escola Veterinário, Universidade Estadual de Londrina, Londrina, PR. 3. Departamento de Medicina Veterinária Preventiva e Saúde Animal, Universidade de São Paulo, São Paulo, SP. 4.Department of Pathology, The Johns Hopkins University School of Medicine, Baltimore, MD, USA. 5. Departamento de Medicina Veterinária Preventiva, Universidade Estadual de Londrina, Londrina, PR.

Address to: Dr. Odilon Vidotto. Dept ${ }^{\circ}$ Medicina Veterinária Preventiva/UEL. Caixa Postal 6001 Campus Universitário, 86055-900 Londrina, PR, Brasil.

Phone: 5543 3371-5876

e-mail: vidotto@uel.br

Received in $12 / 12 / 2009$

Accepted in 14/01/2011

\section{INTRODUCTION}

Spotted fever rickettsioses are caused by bacteria of the genus Rickettsia from the spotted fever group (SFG). R. rickettsii is the etiologic agent of Brazilian spotted fever (BSF) and it is transmitted by Amblyomma spp. tick bites ${ }^{1}$. In Brazil, A. cajennense and $A$. aureolatum are associated with the transmission of $R$. rickettsii to humans and animals ${ }^{1,2}$. In recent decades, BSF has been described in four states of southeastern Brazil, particularly in São Paulo and Minas Gerais ${ }^{3-6}$.

The importance of rickettsiosis is increasing not only due to the identification of new species, but also because its prevalence and distribution are greater than previously suspected ${ }^{7}$. In Brazil, only $R$. rickettsii has been isolated and characterized in humans and this was only in the State of São Paulo ${ }^{8,9}$. Other rickettsiae of the SFG have been isolated in ticks, such as $R$. parkeri and R. belli, and in fleas, R. felis. Recently, $R$. parkeri was responsible for causing a mild disease in the United States ${ }^{10}$. In Brazil, no reports of diseases caused by this rickettsia in humans have been recorded; however, it has already been detected in the ticks A. dubitatum and A. triste in the State of São Paulo ${ }^{11,12}$.

In the State of Paraná, the first case of BSF was notified in the City of São José dos Pinhais, in the southern region of the state, in a man who was infected on a farm ${ }^{13,14}$. Ever since, a variety of serological investigative studies on humans, horses and dogs in different regions of the state indicated positive rates of $R$. rickettsii ranging from $4.7 \%$ to $24.1,5.5 \%$ to $55.6 \%$ and $1.9 \%$ to $22.9 \%$, respectively ${ }^{15-20}$. There are few confirmed cases of the disease in Paraná, but these data suggest that infection by rickettsiae is occurring in both the human and animal populations.

Despite the lack of any data implicating a specific animal species as a $R$. rickettsii amplifying host for ticks in Brazil, several studies conducted since the 1930s suggest that capybaras, opossums 
and wild rabbits might play this role $\mathrm{e}^{21}$. In capybaras (Hydrochoerus hydrochaeris), bacteremia is observed for more than 11 days postinoculation $^{22}$ and A. cajennense feeding on experimentally infected capybaras later transmit the infection by biting other animals $^{23}$. Capybaras are hosts to several tick species, including A. cajennense and A. dubitatum ${ }^{22}$. Despite the lack of evidence regarding the capacity of $A$. dubitatum to transmit $R$. rickettsii, suspicions exist that it may contribute in the transmission of rickettsiae to humans ${ }^{11,24}$.

The Arthur Thomas Municipal Park (ATMP) located in the City of Londrina, Paraná, is a landmark for tourism and also has a large number of staff and daily visitors. In a populational dynamics study with free-living ticks performed in this park, a large population of ticks was verified in the vegetation all year round and staff and visitors are constantly exposed to them ${ }^{25}$. Due to the lack of data concerning the presence of rickettsiae in the parks of Paraná, the objective of this study was to investigate the presence of rickettsiae of the spotted fever group in ticks living in the vegetation and on capybaras in the park and the occurrence of positive serology among staff members.

\section{METHODS}

\section{Area studied}

The ATMP is situated in the City of Londrina, State of Paraná, a nonendemic region for BSF. The City of Londrina (2319'S, $\left.51^{\circ} 10^{\prime} \mathrm{W}\right)$ is located in the central-northern region the State of Paraná, in the southern region of Brazil. It is located at $610 \mathrm{~m}$ above sea level and has a subtropical climate, with rainfall throughout the year, but with a tendency of concentrating rains during the summer months. The annual average temperature is around $20^{\circ} \mathrm{C}^{26}$.

This park is located within the urban perimeter of Londrina, $6 \mathrm{~km}$ from the city center and has a total area of $85.47 \mathrm{ha}$ along the middle course of the Cambé River, which forms a dam inside the park. It stands as one of the last areas of Atlantic forest in northwestern Paraná ${ }^{27}$. The ATMP has diverse fauna, with populations of capuchin monkeys, capybaras, opossums, coatis and agoutis, as well as birds and fishes. The park contains a dam that is surrounded by grass and bushes, where an average of 20 capybaras can be observed for most of the day. In this region, a large number of ticks can be found year round. This place is also commonly visited by the park staff and visitors, which are openly exposed to the attack from these ticks ${ }^{25}$.

\section{Ticks from the environment and from capybaras}

In the ATMP, monthly collections of ticks from the environment were conducted over 12 months, from August 2006 to July 2007. Free-living ticks were collected from the park vegetation near areas where capybaras live on the margins of the dam. To collect ticks from the environment, $\mathrm{CO}_{2}$-baited traps were used to capture nymphs and adults and drag samplings were used to capture larvae ${ }^{28}$. Ticks collected from the park were placed in containers with absolute ethanol and transported to the laboratory where they were counted, separated according to developmental stage (larvae, nymph and adult), and where the adults were identified according to the taxonomic key and morphological characteristics ${ }^{29,30}$ and then maintained in absolute ethanol until DNA extraction. Ticks were collected from the capybaras in 2005 by Londrina State University (Universidade Estadual de Londrina, UEL) and Environmental Agency (Secretaria Estadual do Meio Ambiente, SEMA) staff who monitored the capybara population. These ticks were maintained in pure ethanol in the Laboratory of Parasitology and Parasitic Diseases of the UEL. They were identified by the same taxonomic key mentioned above.

In the period of a year, 3,029 adult ticks, 14,186 nymphs and 25,356 larvae were collected from the environment. Regarding adult ticks, a total of 2,526 (81.9\%) were identified as A. dubitatum and 503 (18.1\%) as A. cajennense ${ }^{25}$ and for ticks collected from capybaras, 40 were identified as $A$. dubitatum and two as $A$. cajennense.

\section{Blood samples}

In December 2007, blood samples were collected by brachial vein puncture from 34 healthy humans who worked in the park. The samples were stored in sterile tubes, identified and transported to the laboratory, where they were centrifuged $(1,500 \mathrm{~g}$ for $10 \mathrm{~min})$ and serum aliquots were placed into labeled microtubes and stored at $-20^{\circ} \mathrm{C}$ until they were tested by indirect immunofluorescence assay (IFA).

\section{DNA extraction}

Extraction of DNA and PCR were performed only for adult ticks. For ticks collected from vegetation, a pool of five ticks was defined as a sample unit, resulting in a total of 100 pools of $A$. cajennense and and 505 of $A$. dubitatum. The size of the sampling extracted from this population was estimated considering a prevalence of approximately $2 \%$, which resulted in 78 and 147 pools of $A$. cajennense and $A$. dubitatum, based on statistics and sample design ${ }^{31}$. All ticks collected from capybaras were submitted for DNA extraction and PCR, consisting of a total of 8 pools of A. dubitatum $(n=40)$ and two $A$. cajennense analyzed individually.

Pooled ticks were previously dried at room temperature. With the help of a sterile surgical blade, a longitudinal section was performed in the middle of the tick. Half of the tick was shredded and DNA extraction was performed as previously described ${ }^{32}$ with minor modifications $s^{33}$. The other half of the tick was maintained at $-20^{\circ} \mathrm{C}$. DNA extraction was performed for each tick and $5 \mu \mathrm{L}$ of each extraction was added to the pool to performed PCR.

\section{Polymerase chain reaction}

Initial oligonucleotides (primers), RpCS.877p (GGGGGCCTGCTCACGGCGG) and RpCS.1258n (ATTGCAAAAAGTACAGTGAACA) were used to amplify a 381 base pair region of the Rickettsia spp. gltA gene ${ }^{34}$. For PCR reactions, $2.5 \mu$ l buffer (10X), $0.2 \mu$ l deoxynucleoside triphosphates (dNTP $1,25 \mathrm{mM}), 1.25 \mu \mathrm{MgCl}_{2}(50 \mathrm{mM}), 3 \mu \mathrm{l}$ of each primer (10pmol), $0.3 \mu \mathrm{l}$ Taq DNA polymerase $(5,000 \mathrm{U} / \mathrm{ml}), 5 \mu \mathrm{l}$ sample, ultrapure

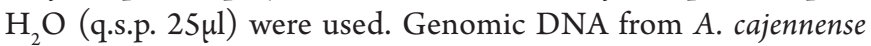
ticks naturally infected with $R$. amblyommii were used as positive controls for PCR reactions and DNA extraction. As a negative control, sterile ultra pure water was used. The stages and conditions of amplification were: initial denaturation at $95^{\circ} \mathrm{C}$ for $5 \mathrm{~min}, 35$ cycles of denaturation at $95^{\circ} \mathrm{C}$ for $20 \mathrm{sec}$, annealing at $48^{\circ} \mathrm{C}$ for $30 \mathrm{sec}$, elongation at $60^{\circ} \mathrm{C}$ for $2 \mathrm{~min}$ and final elongation at $60^{\circ} \mathrm{C}$ for $10 \mathrm{~min}^{33}$.

Amplified products were separated in $1.5 \%$ TBE ( $89 \mathrm{mM}$ Trisborate, $2 \mathrm{~mm}$ EDTA, $\mathrm{pH} 8$ ) agarose gels using 100bp ladders as size markers (100bp DNA ladder; Life Technologies, Invitrogen, Carlsbad, CA, USA). These bands were compared to a standard $123 \mathrm{pb}$ molecular weight marker. Gels were visualized with ethidium bromide under UV illumination and photographed.

\section{Indirect immunofluorescence assay}

All human serum samples were submitted for IFA in the Department of Preventive Veterinary Medicine and Animal Health 
of University of São Paulo (VPS/USP). Slides were prepared as previously described ${ }^{35}$ using two Rickettsia species: $R$. rickettsii (strain Taiaçu $)^{2}$ and $R$. parkeri (strain At 24$)^{12}$. On each slide, a serum previously shown to be nonreactive (negative control) and a known reactive serum (positive control) were tested. Slides were read using an epifluorescent microscope (Olympus, Japan) at 400x magnification and only sera presenting titers against IgG $\geq 64$ were considered positive. Reactions were interpreted as previously described ${ }^{35}$

\section{Statistical analysis}

An epidemiological questionnaire was applied to each subject who submitted blood. To evaluate variables, the Chi square or Fisher exact test and odds ratio calculation with $95 \%$ confidence intervals of were used. $\mathrm{P}$ values $<0.5$ were considered significant. Calculations were performed using the Epi6 program (CDC/Atlanta).

\section{Ethical considerations}

Collection of human blood was approved by the Research Ethics Committee in Research Involving Human Beings of the UEL (protocol no. 125/07).

\section{RESULTS}

\section{Tick PCR}

A total of 225 tick pools were analyzed, including 78 (390 ticks) A. cajennense and 147 (735 ticks) A. dubitatum, collected from the environment. Among the ticks collected from capybaras, 8 A. dubitatum pools ( 40 ticks) were analyzed and 2 A. cajennense were analyzed individually. All pools were negative, including those of the individually analyzed ticks. Positive controls produced bands at the expected locations; negative controls did not produce any bands.

\section{Indirect immunofluorescence assay}

A total of 34 serum samples were collected from humans. All sera were tested by IFA using $R$. rickettsii and $R$. parkeri antigens. Of the 34 total sera analyzed, 7 (20.6\%) reacted against $R$. rickettsii antigen at titers $\geq 64$. Four of these had endpoint titers equal to 64 , 2 titers were 128 and 1 titer was 256 . When $R$. parkeri antigen was used, all were negative.

\section{Epidemiological questionnaire}

Among the 34 subjects who submitted blood samples, 26 (76.5\%) affirmed having been bitten by ticks and of these, 9 (34.6\%) affirmed that they had acquired tick bites only inside the park, while 12 (46.2\%) affirmed having been bitten by ticks inside the park and in other places; 18 (52.9\%) lived in a rural area, 21 (61.8\%) had worked or were working with animals in a rural area; 15 (44.1\%) worked in the park, in jobs involving gardening, security and environmental police, in direct contact with areas infested by ticks.

Among the 7 individuals with reactive serology, 4 (57.1\%) affirmed having acquired tick bites in the park and in other areas, two $(28.6 \%)$ affirmed having acquired tick bites only in the park; $5(71.4 \%)$ lived or worked in rural areas; 3 (42.9\%) worked in the park in direct contact with areas infested by ticks and 4 (57.1\%) had jobs outside the park or within the administrative block. There were no significant associations between the presence of $R$. rickettsii antibodies and the variables evaluated. None of the individuals investigated reported any clinical manifestations related to the BSF.

\section{DISCUSSION}

Regarding the 2 tick species collected from vegetation, A. dubitatum represented $81.9 \%$ of adult ticks and was much more prevalent than A. cajennense. As capybaras are the primary hosts for $A$. dubitatum and A. cajennense, an increased abundance of these species occurs in areas where these animals are established ${ }^{36}$. Reports of capybaras with positive serology for SFG rickettsiae ${ }^{37}$ and reports of these animals with rickettsemia have been published. The circulation of $R$. rickettsii in capybaras was observed for more than 11 days, while a separate study showed that it was possible to infect $A$. cajennense by feeding on experimentally infected capybaras and that these infected ticks could transmit the infection to other animals ${ }^{22,23}$. These data suggest a potential role for capybaras in the BSF cycle and in the cycles of other rickettsiae.

Following analysis of the sample used in this study, the infection rate in the tick population is below $2 \%$. For greater prevalence, at least one pool had to test positive. This infection rate is similar to the rates determined in other works that were performed in nonendemic areas. In the USA, D. variabilis ticks from regions where rocky mountain spotted fever (RMSF) has never been reported showed infection rates of $0.7 \%^{38}$. However, the authors also affirmed that the tick infection rate does not vary from that observed in nonendemic areas and regions where were cases of human RMSF have occurred ${ }^{38}$. This emphasizes the importance of serological evaluations in animals and humans to investigate the transmission of Ricketsia. Infection by Rickettsiae in A. cajennense collected from endemic and nonendemic areas in the State of São Paulo showed no positive results by $\mathrm{PCR}^{33}$. However, after the results were analyzed statistically, in one farm, 206 ticks (the smallest sample) were tested and the prevalence of A. cajennense infected by Rickettsia was estimated at most 1.4\% (upper limit of $95 \%$ confidence interval). Similarly, in other farm, where 353 ticks were tested (the largest sample), the prevalence was at most $0.8 \%$ (upper limit of $95 \%$ confidence interval). Thus, the authors concluded that the incidence of rickettsiae-infected ticks was no more than $0.8 \%$ to $1.4 \%$.

Other studies report the presence of SFG rickettsiae in A. dubitatum in the city of Pedreira, State of São Paulo ${ }^{11,24}$, and concluded that this tick could be an important species in the epidemiology of BSF. Some studies have also reported the presence of R. bellii in these ticks. Labruna et a ${ }^{11}$ verified $40 \%$ of ticks infected by $R$. bellii, values very similar to those determined by Pacheco ${ }^{39}$ in the same area. The latter concluded that if some SFG rickettsiae were circulating in the population studied, the ratio of infected ticks would be lower than $0.36 \%$ and also that the high proportion of ticks infected by R. bellii could inhibit the establishment of other Rickettsia species, owing to rickettsial interference that precludes ovarian infection by more than one rickettsia ${ }^{1,5,40}$.

In this study, seroprevalence in humans was of $20.6 \%$ using $R$. rickettsii antigen. Although no Rickettsiae was identified in the ticks nor were any BSF cases notified in the Londrina region, this rate of seropositivity for people who work in an area at risk of tick bites is considered high. Studies developed in the southeastern region of Brazil verified no reactions or lower seroprevalences (2.8\% - 5.3\%) using IFA and $R$. rickettsii antigen, for human sera from endemic and nonendemic areas ${ }^{3,5,33,41}$. In contrast, other serological studies involving humans in 5 different areas of the State of São Paulo, 4 of which are considered endemic and 1 nonendemic ${ }^{42}$, 
verified $R$. rickettsii seroprevalences that varied from $10.1 \%$ to $19 \%$. Seroprevalence in the nonendemic area was of $17.8 \%$, similar to the results of the present study. The difference was that in the study conducted in the State of São Paulo, sera also reacted when tested with other antigens, such as $R$. parkeri and $R$. felis. In the present study, no serum reactions occurred with $R$. parkeri. This alone does not indicate that $R$. rickettsii is responsible for the immune response generated in the seropositive subjects, only that it was generated by a SFG rickettsia.

Another serological investigation on humans realized in rural areas of two towns neighboring Londrina revealed antibody rates for $R$. rickettsii similar to those verified in this study: $9.4 \%$ in the city of Arapongas and $24.1 \%$ in Alvorada do Sul ${ }^{20}$. The differential diagnosis for BSF is difficult, when comparing with other diseases commonly identified in the Londrina area, such as leptospirosis and dengue fever. Given this fact, the number of genuine positive cases may be underestimated, since less severe cases may be misdiagnosed or diagnosed inconclusively.

Through the application of the epidemiological questionnaire, it was possible to observe that the majority of humans, regardless of serological results, reported tick bites inside the park and in other areas. Moreover, many of these individuals currently work or have worked with animals in rural areas. Related to this finding and mainly due to the fact that there were no positive ticks identified in the PCR, it is difficult to clearly establish a relation between human infection and the ticks present in the park, though this does not preclude the existence of rickettsia-infected ticks in the area.

Future studies must include other vertebrate hosts that inhabit the park and surveys of a wider diversity of ticks; moreover, serological tests using a broader range of antigens or more specific methods could help to more clearly define the presence or absence of rickettsial activity within the park.

\section{ACKNOWLEDGMENTS}

The authors wish to thank the Secretarias de Saúde e do Meio Ambiente do Município de Londrina for their support in collecting the human blood samples and during tick collection in Arthur Thomas Park.

\section{CONFLICT OF INTEREST}

The authors declare that there is no conflict of interest.

\section{FINANCIAL SUPPORT}

CNPq, Fundação Araucária do Paraná and CAPES.

\section{REFERENCES}

1. Dias E, Martins AV. Spotted fever in Brazil. A J Trop Med 1939;19:103-108.

2. Pinter A, Labruna MB. Isolation of Rickettsia rickettsii and Rickettsia bellii in cell culture from the tick Amblyomma aireolatum in Brazil. Ann N Y Acad Sci 2006; 1078:523-529.

3. Sexton DJ, Muniz M, Corey GR, Breitschwerdt EB, Hegarty BC, Dumler S, et al. Brazilian spotted fever in Espírito Santo, Brazil: description of a focus of infection in a new endemic region. A J Trop Med Hyg 1993; 49:222-226.

4. Lemos ERS, Alvarenga FBF, Cintra ML, Ramos MC, Padoock CD, Ferebee TL, et al. Spotted fever in Brazil: a seroepidemiological study and description of clinical cases in a endemic area in the state of Sao Paulo. A J Trop Med Hyg $2001 ; 65: 329-334$

5. Rozental T, Bustamante MC, Amorim M, Serra-Freire NM, Lemos ERS. Evidence of spotted fevre group rickettsiae in state of Rio de Janeiro, Brazil. Rev Inst Med Trop Sao Paulo 2002; 44:155-158.

6. Galvão MAM, Calic SB, Chamone CB, Mafra CL, Cesarino Filho G, Olano JP, et al. Spotted fever rickettsiosis in Coronel Fabriciano, Minas Gerais State. Rev Soc Bras Med Trop 2003; 36:479-481.

7. Galvão MAM, Silva LJ, Nascimento EMM, Calic SB, Souza R, Bacellar F. Rickettsioses no Brasil e Portugal: ocorrência, distribuição e diagnóstico. Rev Saude Publica 2005; 39:850-856.

8. Melles HHB, Colombo S, Silva MV. Febre maculosa: isolamento de Rickettsia em amostra de biópsia de pele. Rev Inst Med Trop Sao Paulo 1992; 34:37-41.

9. Nascimento EM, Gehrke FS, Maldonado RA, Colombo S, Silva LJ, Schumaker TTS. Detection of a brazilian spotted fever infection by polymerase chain reaction in a patient from the State of São Paulo. Mem Inst Oswaldo Cruz 2005; 100:277-279.

10. Paddock CD, Summer JW, Comer JA, Zaki SR, Goldsmith CS, Goddard J, et al. Rickettsia parkeri: a newly recognized cause of spotted fever rickettsiosis in the United States. Clin Infect Dis 2004; 38:805-811.

11. Labruna MB, Whitworth T, Horta MC, Bouyer DH, Mcbride JW, Pinter A, et al. Rickettsia species infecting Amblyomma cooperi ticks from an area in the state of São Paulo, Brazil, where Brazilian spotted fever is endemic. J Clin Microbiol 2004; 42:90-98.

12. Silveira I, Pacheco RC, Szabó MPJ, Ramos HGC, Labruna MB. First report of Rickettsia parkeri in Brazil. Emerg Infect Dis 2007; 13:1111-1113.

13. Freitas MC, Molento MB, Biondo AW. Febre maculosa: primeiros relatos do Paraná [Internet]. Curitiba: Conselho Regional de Medicina Veterinária do Paraná; 2009 Jul 20 [cited 2011 Jan 04]. Available from: http://www.crmv-pr. org.br/?p=imprensa/artigo_detalhes\&id=55/.

14. Ministério da Sáude. Casos de febre maculosa no Brasil. Brasília: Ministério da Saúde; [cited 2011 Jan 04]. Available from: http://portal.saude.gov.br/portal/ saude/profissional/area.cfm?id_area $=1555 /$.

15. Otomura FH, Sangioni LA, Pacheco RC, Labruna MB, Galhardo JA, Ribeiro MG, et al. Anticorpos anti-rickettsias do grupo da febre maculosa em equídeos e caninos no norte do Paraná, Brasil. Arq Bras Med Vet Zootec 2010; 62:761-764.

16. Tamekuni K, Toledo RS, Silva Filho MF, Haydu VB, Pacheco RC, Cavicchioli JH, et al. Serosurvey of antibodies against spotted fever group Rickettsia spp. in horse farms in Northern Paraná , Brazil. Rev Bras Parasitol Vet 2010; 19:1-3.

17. Freitas MCDO, Grycajuk M, Molento MB, Bonacin J, Labruna MB, Pacheco RC, et al. Brazilian spotted fever in cart horses in a non-endemic area in Southern Brazil. Rev Bras Parasitol Vet 2010; 19:130-131.

18. Fortes FS. Infecção por Rickettsia spp. em cães no município de São José dos Pinhais e em capivaras no município de Foz do Iguaçu, Paraná, Brasil. [Master Thesis]. [Curitiba (PR)]: Universidade Federal do Paraná; 2010, 105 p.

19. Toledo RS, Tamekuni K, Silva Filho MF, Haydu VB, Barbieri ARM, Hiltel AC, et al. O. Infection by Spotted Fever Rickettsiae in people, dogs, horses and ticks in Londrina, Parana State, Brazil. Zoonosis Public Health. In press 2010.

20. Tamekuni K. Prevalência de anticorpos contra rickettsias do grupo da Febre Maculosa em humanos, cães e equinos e identificação molecular de Rickettsia spp em carrapatos na região Norte do Paraná. [Doutoral Thesis]. [Londrina (PR)]: Universidade Estadual de Londrina; 2009, 65 p.

21. Labruna MB. Cultivo celular de riquétsias no Brasil. In: XIV Congresso Brasileiro de Parasitologia Veterinária e II Simpósio Latino-Americano de Rickettsioses, 2006, Ribeirão Preto. Ribeirão Preto: CBPV: Programas e Resumos; 2006. p.132-133.

22. Travassos J, Vallejo A. Comportamento de alguns cavídeos (Cavia aperea e Hydrochoerus capybara) às inoculações experimentais do vírus da febre maculosa. Possibilidade de estes cavídeos representarem o papel de depositários transitórios do vírus na natureza. Mem Inst But 1942; 15:73-86.

23. Travassos J, Vallejo A. Possibilidade de Amblyomma cajennense se infectar em Hydrochoerus capybara experimentalmente inoculado com o vírus da febre maculosa. Mem Inst But 1942; 16:87-90.

24. Lemos ERS, Melles HHB, Colombo S, Machado RD, Coura JR, Guimarães MAA, et al. Primary isolation of spotted fever group rickettsiae from Amblyomma cooperi collected from Hydrochaeris hydrochaeris in Brazil. Mem Inst Oswaldo Cruz 1996; 91:273-275. 
25. Toledo RS, Tamekuni K, Haydu VB, Vidotto O. Seasonal dynamics of Amblyomma ticks (Acari: Ixodidae) in an urban Park of Londrina City, Parana, Brazil. Rev Bras Parasitol Vet 2008; 17:(suppl 1):50-54.

26. Wikipedia. Londrina [Internet]. [cited 2008 Jan]. Available from: http//www. wikipedia.org/wiki/Londrina/.

27. Parque Arthur Thomas: Histórico. Londrina [Internet]. [cited 2008 Jan]. Available from: http://www.Parquearthurthomas.com.br/.

28. Oliveira PR, Borges LMF, Lopes CML, Leite RC. Population dynamics of the free-living stages of Amblyomma cajennense (Fabricius, 1787) (Acari: Ixodidae) on pastures of Pedro Leopoldo, Minas Gerais State, Brazil. Vet Parasitol 2000; 92:295-301.

29. Aragão HB, Fonseca F. Notas de Ixodologia, VIII. Lista e chave para os representantes da fauna ixodológica brasileira. Mem Inst Oswaldo Cruz $1961 ; 59: 115-129$

30. Guimarães JH, Tucci HEC, Barros-Battesti DM. Ectoparasitos de importância veterinária. São Paulo: Editora Plêiade; 2001.

31. Cannon RM, Roe RT. Livestock Disease Surveys: A Field Manual for Veterinarians. Canberra: Australian Bureau of Animal Health; 1982

32. Chomkzynsk PA. Reagent for the single step simultaneous isolation of RNA, DNA and proteins from cell and tissue samples. Biotechniques 1993; 15:532-536.

33. Sangioni LA, Horta MC, Vianna SMG, Soares RM, Galvão MAM, Schumaker TTS, et al. Rickettsial infection in animals and Brazilian spotted fever endemicity. Emerg Infect Dis 2005; 11:265-269.

34. Regnery RL, Spruill CL, Plikaytis BD. Genotypic identification of Rickettsiae and estimation of intraspecies sequence divergence for portions of two Rickettsial genes. J Bacteriol 1991; 173:1576-1589.

35. Horta MC, Labruna MB, Sangioni LA, Vianna MCB, Gennari SM, Galvão MAM, et al. Prevalence of antibodies to Spotted Fever Group Rickettsiae in humans and domestic animals in a Brazilian Spotted Fever-Endemic area in the State of São Paulo, Brazil: Serologic evidence for infection by Rickettsia rickettsii and another spotted fever group Rickettsia. Am J Trop Med Hyg 2004; 71:93-97.

36. Estrada DA, Shumaker TTS, Souza CE, Rodriguez Neto E, Linhares AX. Detecção de riquetsias em carrapatos do gênero Amblyomma (acari: Ixodidae) coletados em parque urbano do município de Campinas, SP. Rev Soc Bras Med Trop 2006; 39:68-71.

37. Souza CE, Calic SB, Camargo MCGO, Savani ESM, Souza SSL, Lima CLV, et al. O papel da capybara Hydrochaeris hydrochaeris na cadeia epidemiológica da febre maculosa brasileira. Rev Bras Parasitol Vet 2004; 13: 203-205.

38. Magnarelli LA, Anderson JF, Philip RN, Burgdorfer W, Casper EA. Endemicity of spotted fever group rickettsiae in Connecticut. A J Med Trop Hyg 1981; 30:715-721.

39. Pacheco RC. Pesquisa de Rickettsia spp em carrapatos Amblyomma dubitatum Neumann 1899 e Amblyomma triste Kosh 1844, provenientes do Brasil e Uruguai, respectivamente. [Doutoral Thisis]. [São Paulo]: Universidade de São Paulo; 2007. 52 p.

40. Burgdorfer W. Mountain spotted fever and scrub typhus, 1988: In: Walker DH, editor. Biology of Rickettsial Diseases. Florida: Ed. Boca Raton: CRC Press; 1988. p. 34-50.

41. Pinter A, Horta MC, Pacheco RC, Moraes-Filho J, Labruna MB. Serosurvey of Rickettsia spp. in dogs and humans from an endemic area for brazilian spotted fever in the state of São Paulo, Brazil. Cad Saude Publica 2008; 24:247-252.

42. Horta MC, Labruna MB, Pinter A, Linard PM, Schumaker TTS. Rickettsia infection in five areas of the state of São Paulo, Brazil. Mem Inst Oswaldo Cruz 2007; 102:793-801. 